\title{
Nucleic acid splicing events occur frequently during macronuclear development in the protozoan Oxytricha nova and involve the elimination of unique DNA
}

\author{
Rosa Maria Ribas-Aparicio, ${ }^{1}$ Jason J. Sparkowski, Anne E. Proulx, John D. Mitchell, and Lawrence A. \\ Klobutcher \\ Department of Biochemistry, University of Connecticut Health Center, Farmington, Connecticut 06032 USA
}

\begin{abstract}
During its life cycle, the hypotrichous ciliated protozoan Oxytricha nova transforms a copy of its chromosomal micronucleus into a transcriptionally active macronucleus which contains exclusively linear, gene-sized DNA molecules with an average size of about 2.2 kilobase pairs (kbp). The micronuclear precursors of two macronuclear DNA molecules have been examined. Each was found to contain at least five blocks of DNA sequences that are absent in the mature macronuclear DNA molecule. These blocks of sequences, referred to as internal eliminated sequences (IESs), must be removed by a nucleic acid breakage and joining process during development. The data obtained to date indicate that IESs are common and suggest that greater than 60,000 IES removal events occur during macronuclear development. Additional analyses indicate that IESs represent a portion of the unique micronuclear DNA sequences known to be eliminated during development. Comparisons of the sequences of IESs revealed common organizational features and some limited primary sequence homologies that suggest models for their developmental excision.
\end{abstract}

[Key Words: Oxytricha nova; macronuclear development; internal eliminated sequences; micronuclear DNA sequences; transcription]

Received January 19, 1987; revised version received and accepted March 9, 1987.

Developmental elimination of specific DNA sequences has long been known to occur in the somatic cells of a variety of organisms, including crustaceans (Beerman 1977), insects (Metz 1938; Brunn and Kalthoff 1983), and nematodes (Boveri 1899; Roth and Moritz 1981). The functional significance of such developmental DNA elimination processes is poorly understood. In three cases, however, DNA elimination events are known to be required for correct gene expression. Specific DNA rearrangement events involving DNA elimination are associated with both the expression of immunoglobulin genes in B cells and with the expression of T-cell receptor genes (Hood et al. 1985). DNA elimination is also associated with the expression of nitrogen fixation genes in the cyanobacterium Anabaena (Golden et al. 1985).

To understand better the function and molecular mechanisms of developmental DNA elimination in lower eukaryotes, we have examined such events in $O x$ ytricha nova. O. nova, and other hypotrichous ciliated protozoa, undergo an extensive genome reorganization

'Present address: Departamento de Microbiologia, Escuela Nacional de Ciencias Biologicas del Instituto Politecnico Nacional, Mexico City, Mexico. process during their life cycle (Ammermann et al. 1974; Prescott 1983; Roth et al. 1985). These unicellular organisms are able to alter their genomes drastically because each cell possesses two distinct nuclei: the micronucleus and the macronucleus. The micronucleus contains a complex genome with DNA organized into chromosomes. It is, however, transcriptionally inert and functions primarily as a germ line nucleus, maintaining the genetic continuity of the organism through successive generations. The macronucleus is responsible for all transcription during the vegetative growth of the organism, but has a highly unusual genetic organization. The macronuclear genome is composed exclusively of small, linear DNA molecules with an average size of 2.2 kilobase pairs (kbp) (Swanton et al. 1980b). Since each macronuclear DNA molecule appears to encode a single function (e.g., Kaine and Spear 1982; Helftenbein 1985), and most appear to be transcribed (Nock 1981), they have been referred to as "macronuclear genes."

Despite their differing organization and function in the cell, the macronucleus and micronucleus are related. During each sexual phase of the life cycle, the macronucleus is destroyed and a new one is generated from a mi- 
totic copy of the micronucleus (Ammermann et al. 1974; Prescott 1983). The transformation of the chromosomal micronuclear genome into a macronucleus occurs over a period of approximately $100 \mathrm{hr}$ and involves a number of types of rearrangements. In addition to the fragmentation of the chromosomes to generate the macronuclear genes, all repetitive DNA and $95 \%$ of the unique DNA sequences are eliminated from the micronuclear genome during macronuclear development (Lauth et al. 1976). Simple octanucleotide repeats of the sequence 5'-CCCCAAAA-3' $\left(\mathrm{C}_{4} \mathrm{~A}_{4}\right.$ repeats; Oka et al. 1980; Klobutcher et al. 1981; Pluta et al. 1982) are also added to the ends of macronuclear DNA molecules (Dawson and Herrick 1984; Klobutcher et al. 1984). These terminal sequences appear to serve as telomeres for the linear macronuclear DNA molecules (Pluta et al. 1984). Finally, DNA amplification occurs during development, as most macronuclear genes are present in a single copy in the micronucleus, but are present, on average, in 1000 copies in the macronucleus (Lauth et al. 1976).

We have previously defined an additional type of rearrangement event by comparing the organization of recombinant clones of the micronuclear and macronuclear copies of a randomly chosen 800 -bp macronuclear DNA molecule of $O$. nova referred to as the $\mathrm{C} 2$ gene (Klobutcher et al. 1984). The micronuclear copy of the C2 gene was found to have three short internal blocks of DNA sequence not present in the mature macronuclear DNA molecule. These internal eliminated sequences (IESs) must be removed from the gene during macronuclear development by a nucleic acid breakage and joining, or splicing, process.

To determine if IESs are common in the micronuclear precursors of macronuclear DNA molecules, we have examined the micronuclear chromosomal organization of two additional macronuclear genes in O. nova. In both cases multiple IESs were observed, indicating that IESs are common and that DNA elimination by nucleic acid splicing is a frequent event during development. DNA sequence comparisons of nine IESs have revealed common sequence features that suggest models for their developmental removal. Finally, additional studies have been performed to demonstrate that IESs represent a portion of the unique DNA sequences eliminated during macronuclear development.

\section{Results}

\section{Micronuclear organization of the R1 gene}

To determine if IESs are common, the micronuclear organization of additional macronuclear DNA molecules was examined. A $1.05-\mathrm{kbp}$ macronuclear DNA molecule, referred to as the R1 gene, was first analyzed. The

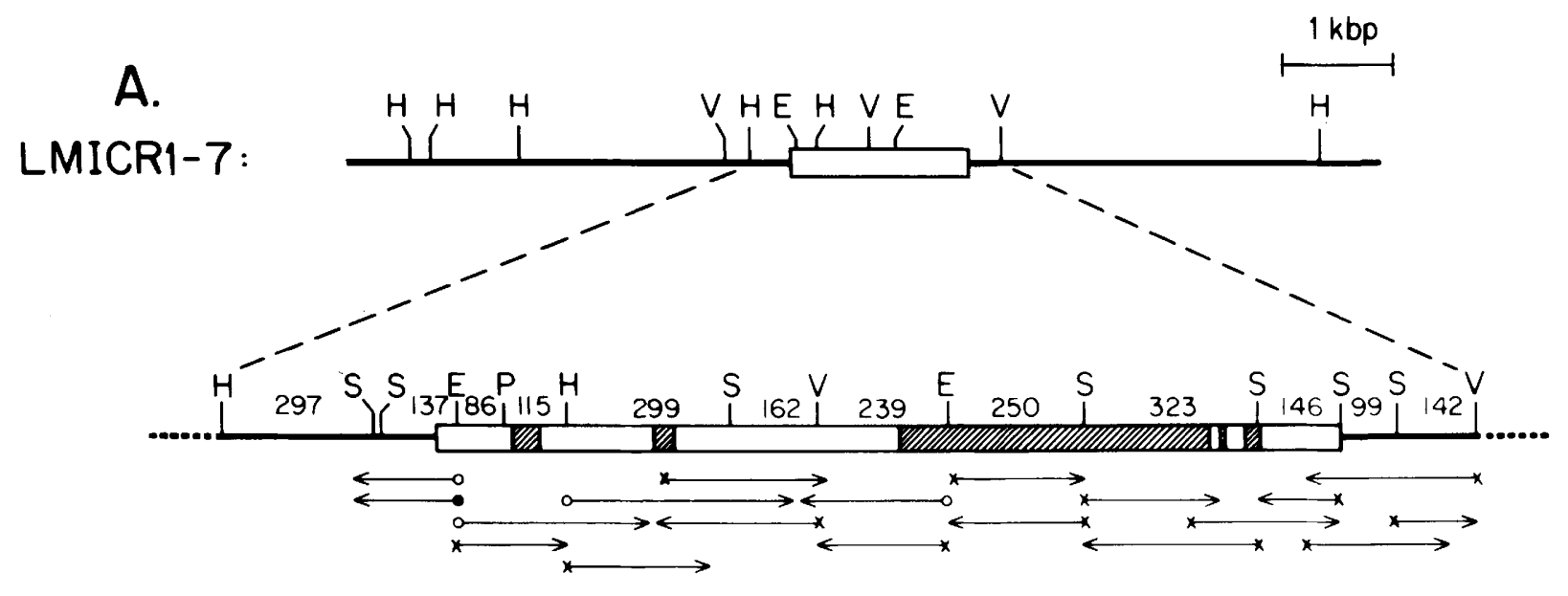

B.
PMACR1 :

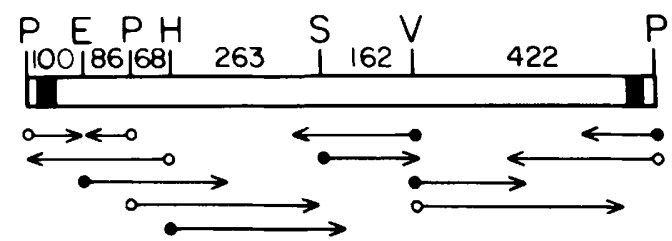

Figure 1. Micronuclear and macronuclear organization of the $\mathrm{R} 1$ gene. (A) Restriction map of the micronuclear insert in clone LMICR 1-7. The region of LMICR 1-7 containing the R l gene (open box) is enlarged to show its restriction map and the location of IESs (hatched boxes). $(B)$ Restriction map of the macronuclear DNA insert of the clone pMACR1. Note that the terminal PstI sites were formed during construction of the clone and are not present in the native macronuclear DNA molecule. The macronuclear R1 gene starts at the solid boxes which represent the $5^{\prime}-\mathrm{C}_{4} \mathrm{~A}_{4}-3^{\prime}$ repeats. $(\mathrm{P})$ PstI; $(\mathrm{E})$ EcoRI; $(\mathrm{H})$ HindIII; $(\mathrm{V})$ PvuII; (S) Sau3A. All PvuII and Sau3A sites are not shown in the complete map of LMICR1-7. Numbers indicate the length of restriction fragments in base pairs. The strategy used in sequencing each of the clones is shown below the restriction maps. Arrows indicate extent of sequence determined from 5' $(0)$ and $3^{\prime}(O)$ ends by the chemical method as well as the dideoxy chain-termination method $(\times)$. 
restriction map of a macronuclear $\mathrm{Rl}$ gene clone, pMACR1 (Klobutcher et al. 1986), was determined and is shown in Figure 1B. Southern hybridization experiments were performed using pMACR 1 to probe restriction digests of total macronuclear DNA to check the integrity of the clone (Fig. 2A). In the EcoRI, HindIII, PstI, and PVuII digests, DNA fragments of 0.98, 0.82, 0.89, and $0.65+0.40 \mathrm{kbp}$, respectively, were detected, as expected from the restriction map of pMACR1. These results indicate that the pMACRl clone contains a faithful representation of a $1.05-\mathrm{kbp}$ macronuclear DNA molecule.

In addition, however, the hybridization results indicate that a second form, or version, of the $\mathrm{R} 1$ gene exists in the macronucleus. In the EcoRI, PstI, and PvuII digests some macronuclear DNA molecules homologous to pMACR1 were not cut by these enzymes (Fig. 2A). Control experiments ruled out partial restriction digests of macronuclear DNA as an explanation for these results (see Materials and methods). Hybridization to total macronuclear DNA doubly digested with the relevant restriction enzymes indicated that there is only one additional form of the R1 gene, which lacks recognition sites for EcoRI, PstI, and PvuII (Fig. 2A, lanes 6-8). Variant forms have been observed for other macronuclear DNA molecules in O. nova (Klobutcher et al. 1984), as well as other hypotrich species (Oka and Honjo 1983; Cartinhour and Herrick 1984). It is likely that at least some of the variant forms are the result of allelic variation, as the hypotrich cell lines used in the laboratory are not inbred strains.

A number of micronuclear clones were isolated that shared homology with pMACR1. Initial characterizations of these clones revealed that one, LMICR 1-7, con- tained EcoRI, PstI, and PvuII sites within the region bearing homology to pMACR1, and was likely to contain the precursor of this form of the $\mathrm{R} 1$ gene. A restriction map of LMICR1-7 is shown in Figure 1A. Hybridization experiments to digests of total micronuclear DNA were performed to confirm the integrity of this clone and to determine if two forms of the $\mathrm{R} 1$ gene also exist in the micronuclear genome. When the internal 493-bp $P_{S t I}-P_{V u I I}$ restriction fragment of pMACR1 was used to probe micronuclear DNA digested with HindIII, 4.6-kbp fragments were detected (Fig. 2B), as expected from the restriction map of LMICR1-7 (Fig. 1A). In addition, 2.3kbp DNA fragments were detected, indicating that a second form of the R1 gene exists in the micronucleus. Similarly, in a PvuII digest of micronuclear DNA the expected $1.3-\mathrm{kbp}$ fragments were observed along with an additional band at $2.6 \mathrm{kbp}$ (Fig. 2B). Thus, the data indicate that there are also a minimum of two forms of the $\mathrm{Rl}$ gene in the micronucleus.

To localize IESs, the complete sequences of the R1 genes in macronuclear clone pMACR1 and micronuclear clone LMICR 1-7 were determined using the strategies shown in Figure 1. The macronuclear R1 gene was found to contain telomeric $\mathrm{C}_{4} \mathrm{~A}_{4}$ repeats bounding a region of 989 bp (Figs. 1 and 3). The micronuclear R1 gene lacked these terminal repeat sequences, as has been observed previously for the micronuclear copies of other macronuclear genes (Klobutcher et al. 1984, 1986; the nature of DNA sequences flanking macronuclear genes in the chromosome will be discussed in detail elsewhere). In addition, the sequence of the R1 gene in LMICR 1-7 contained five IESs (Fig. 3). Aside from these differences, the sequences of the R1 genes in pMACR1 and LMICR1-7 were identical (Fig. 3), providing strong evidence that

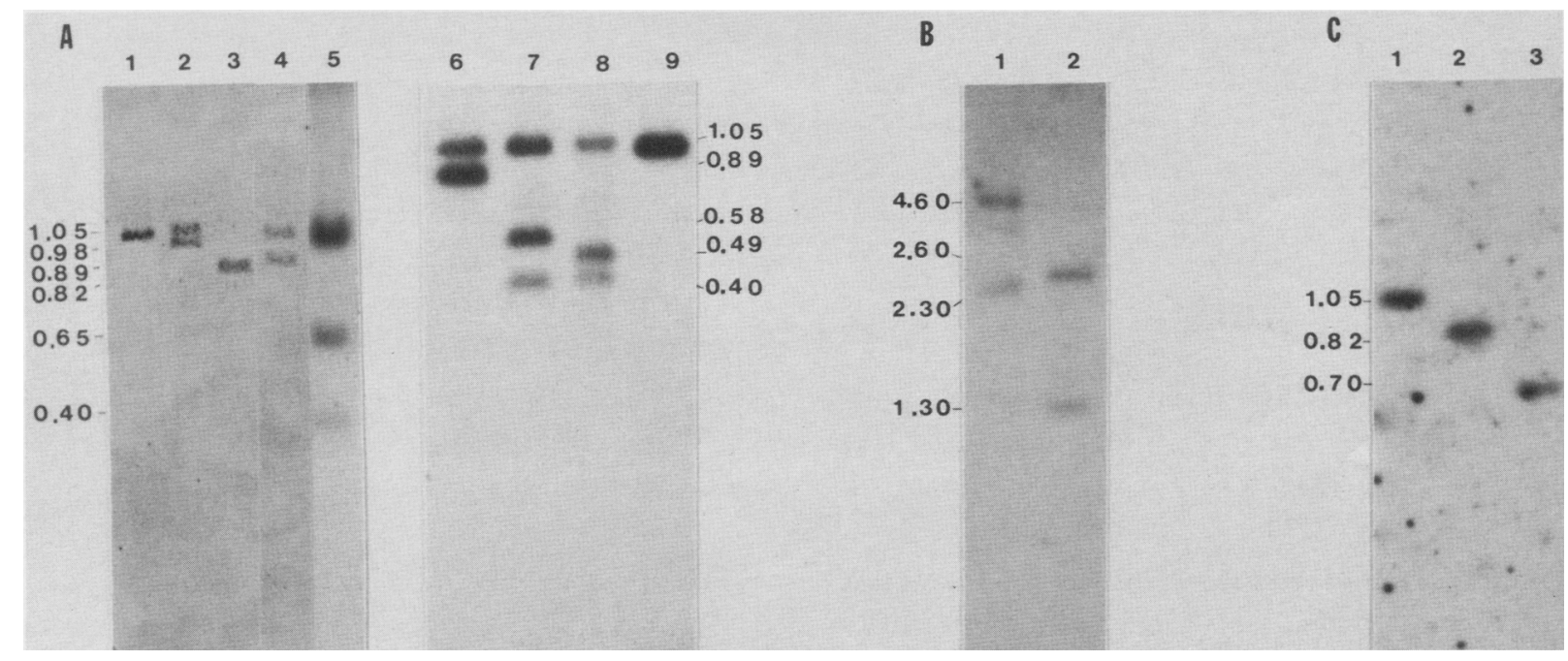

Figure 2. Hybridization of R1 gene clones to genomic macronuclear and micronuclear DNAs. (A) Autoradiograph of the hybridization of pMACRl to a Southern blot containing native macronuclear DNA (lanes 1 and 9) and macronuclear DNA digested with EcoRI (lane 2), HindIII (lane 3), PstI (lane 4), PvuII (lane 5), EcoRI + PstI (lane 6), PvuII + EcoRI (lane 7), and PvuII + PstI (lane 8). (B) Hybridization of the 493-bp PstI-PvuII DNA fragment of pMACR1 to micronuclear DNA digested with HindIII (lane 1) and PvuII (lane 2). (C) Hybridization of the 700-bp HindIII-EcoRI fragment of LMICR1-7 to a Southern blot containing: (lane 1) $0.05 \mu g$ native macronuclear DNA; (lane 2) $0.05 \mu \mathrm{g}$ of HindIII + EcoRI macronuclear DNA; and (lane 3) $1.0 \mu \mathrm{g}$ of HindIII + EcoRI micronuclear DNA. In all cases, the sizes of hybridizing DNA molecules are indicated in kbp. 
Ribas-Aparicio et al.

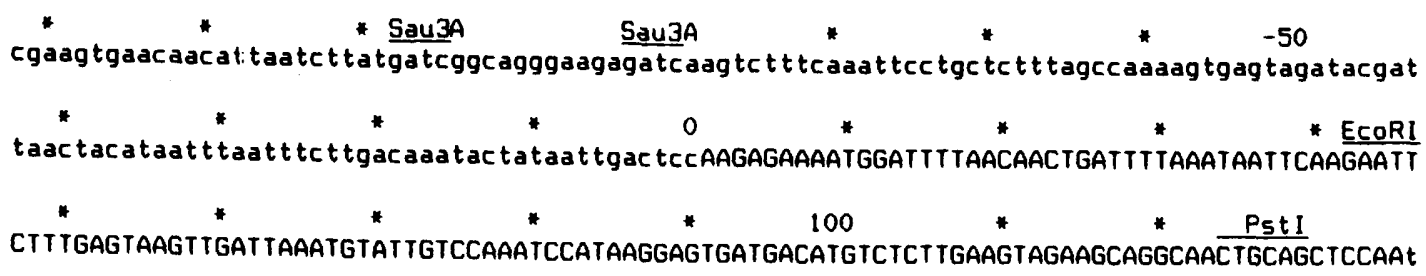

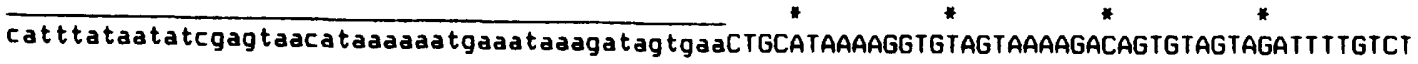
* * HindIII * * * * * *

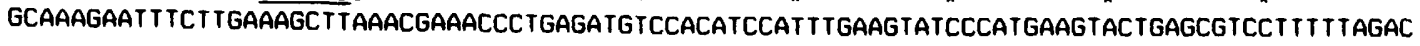
* * * 300 * * * * *

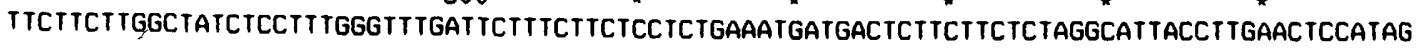
* - * * * * 400 * Catgtatt tat taagattagagactaatgagtagc TAAGTGGGATTGAGAGAGGCTGTCTAATTACTTGCTCATCTTCATGGACT tgttagc * * * * Sauza * * * * * *

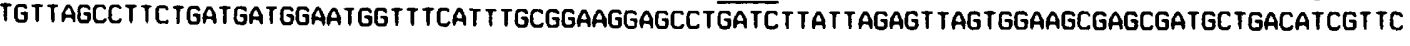

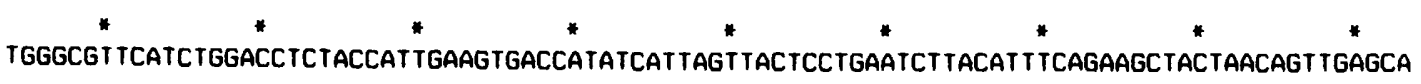
600 PVull * * * * * * * * * * * * * * * *

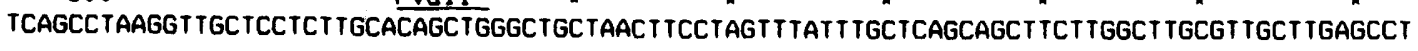

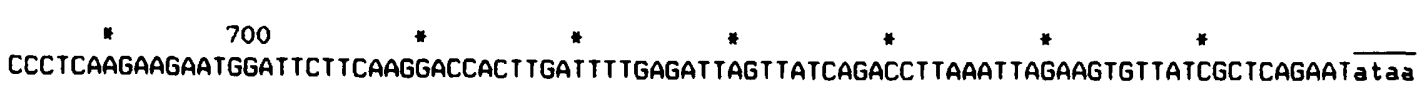

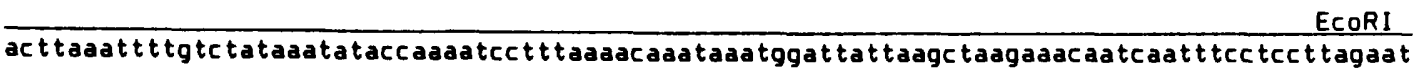
$\overline{\text { tccaagatactctagtac taaataagatgagatt tgatt tgaagactgtaat tcatacgggaat taagegttgagaatcctt }}$ $\overline{\text { agaat tatggaaact tgat tcag taaatatggctgctctatagctataat tcattctgaactaaagctgcaatatccaagag }}$ Sau $3 A$ tcattatacaaattcgtaaataatacaataetttat tatttctaattctcatacctcttgatcattgaaataaaatgaac $\overline{\text { cataatcttctatt tat taatgattaatctatattagattaattaaccaactaaatacaataactgttaaaadcgaatgagt }}$

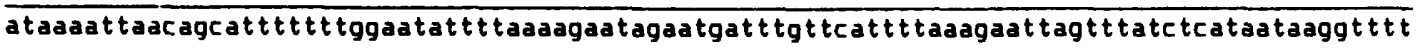

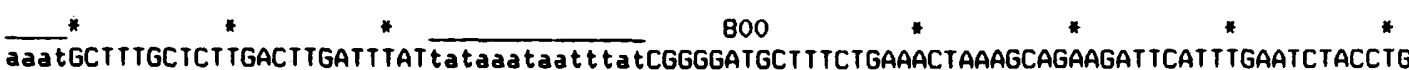
* Sau3a $* * *$ * *

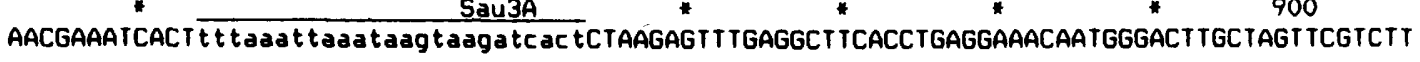
* * * * * * * * * Sauza

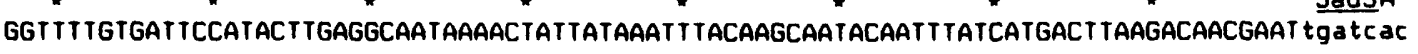

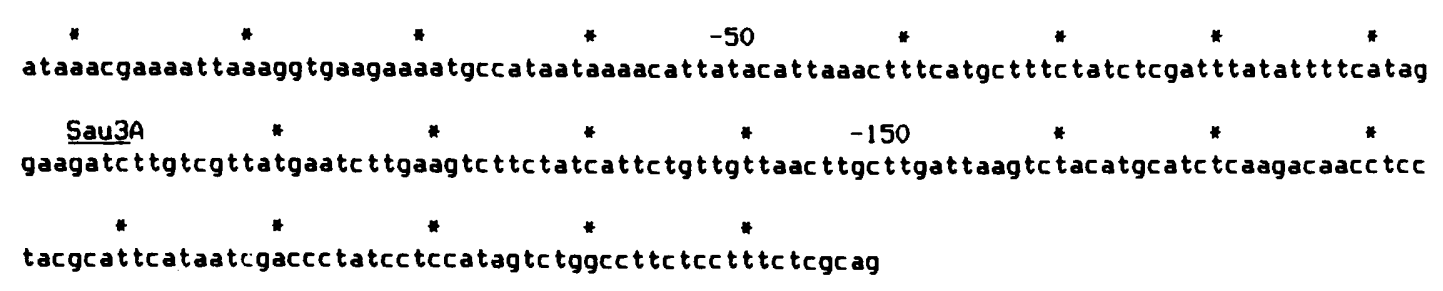

Figure 3. (See facing page for legend.) 
LMICR1-7 contains the developmental precursor of pMACR1. The lengths of the five IESs are 47, 36, 548, 14 , and 25 bp (IES1-IES5, respectively) and they are distributed throughout the entire length of the micronuclear Rl gene. Three of the IESs are similar in size to those previously observed in the $\mathrm{C} 2$ gene (Klobutcher et al. 1984), but the 548-bp IES3 and the 14-bp IES4 represent the largest and smallest IESs observed to date.

A hybridization experiment was performed next to determine if the other micronuclear form(s) of the R1 gene also contains IESs. The 700-bp HindIII-EcoRI fragment of LMICR1-7, which contains all of IES2 and a portion of IES3, was used to probe a blot containing total macronuclear and micronuclear DNAs both doubly digested with HindIII and EcoRI. In macronuclear DNA, 815-bp fragments were detected (Fig. 2C), which represent the major portion of the R1 gene extending from the invariant HindIII site to the right terminus. In the HindIII-EcoRI digest of micronuclear DNA, all homologous fragments were $700 \mathrm{bp}$ in length, as in LMICR 1-7. Thus, it appears that at least IES2 and IES3 are present in all micronuclear copies of the R1 gene, and uniformly absent in all macronuclear copies.

\section{IESs in the C3 gene}

A second macronuclear DNA molecule, the 2.85-kbp C3 gene, was examined for the presence of IESs in its $\mathrm{mi}$ cronuclear precursor. Recombinant clones containing two variant macronuclear forms of the $\mathrm{C} 3$ gene have been isolated, along with two micronuclear clones that appeared to be their developmental precursors (Klobutcher et al. 1986). Southern hybridization analyses using the two macronuclear clones to probe restriction digests of total macronuclear DNA were consistent with these two clones representing the only two forms of the C3 gene in the macronucleus (data not shown). In the micronucleus, however, similar Southern hybridization analyses indicated that, in addition to the two cloned versions of the $\mathrm{C} 3$ gene, a third version also exists. The inferred restriction map of this third version differed drastically from those of the two C3 gene forms present in the macronucleus, suggesting that the third micronuclear form of the $\mathrm{C} 3$ gene was not processed during development (data not shown).

For this study, the macronuclear clone LMAC3-G and micronuclear clone LMIC2-5 were analyzed in greater detail (Fig. 4A). With the exception of a single HincII restriction site (discussed below), the two clones displayed similar restriction maps in their $\mathrm{C} 3$ gene regions, suggesting that LMIC2-5 does indeed contain the micronuclear precursor of the macronuclear $\mathrm{C} 3$ gene represented by LMAC3-G. To establish this point more firmly, ap- proximately $150 \mathrm{bp}$ of the terminal DNA sequences of the $\mathrm{C} 3$ gene in each clone were determined using the strategy shown in Figure 4A. The terminal sequences of the micronuclear and macronuclear $\mathrm{C} 3$ genes were found to be identical, indicating that the LMIC2-5 clone does contain the developmental precursor of the macronuclear $\mathrm{C} 3$ gene in the recombinant clone LMAC3-G. However, two differences in the sequence organization of the micronuclear and macronuclear clones were observed. The first difference was the expected lack of $\mathrm{C}_{4} \mathrm{~A}_{4}$ repeats at the ends of the micronuclear copy of the $\mathrm{C} 3$ gene. The second difference was the presence of a 53-bp IES located $150 \mathrm{bp}$ from the left end of the micronuclear C3 gene (IES1; Fig. 4A).

Detailed restriction mapping and Southern hybridization analyses were next performed to determine if additional IESs were present in the micronuclear C3 gene. For example, the 240-bp HindIII fragment of LMAC3-G was isolated and used to probe a Southern blot containing HindIII digests of the macronuclear and micronuclear clones (Fig. 4B). As expected, a 240-bp fragment was detected in the HindIII digest of LMAC3-G. In the HindIII digest of LMIC2-5, however, a homologous 270 bp fragment was detected, indicating that one or more IESs, totalling approximately $30 \mathrm{bp}$, are contained within this portion of the micronuclear $\mathrm{C} 3$ gene. On the basis of similar analyses, the 950-bp BamHI-HindIII macronuclear fragment corresponds to an 1100-bp fragment in the micronuclear clone (Fig. 4C), and the 210-bp EcoRI-BamHI macronuclear fragment is about $30 \mathrm{bp}$ larger in the micronuclear $\mathrm{C} 3$ gene (Fig. 4D).

Evidence for IESs in the leftward region of the micronuclear C3 gene was also obtained, but the analysis was more complicated because the macronuclear clone contains a HincII site absent in the micronuclear clone (Fig. 4A). This interpretation of the restriction maps is supported by the fact that both the 580-bp HincII and 280-bp HincII-EcoRI fragments of LMAC3-G share homology with the 1020-bp HincII-EcoRI fragment of LMIC2-5 (Figs. 4E, F). However, the homologous interval in the micronuclear clone is about $160 \mathrm{bp}$ larger than the two corresponding fragments of the macronuclear clone. These extra $160 \mathrm{bp}$ could be organized as a single IES or as multiple IESs within this region of the micronuclear C3 gene.

The existence of the extra HincII site in the macronuclear C3 gene clone LMAC3-G is intriguing. At face value, the existence of this restriction site in the macronuclear clone suggests that LMIC2-5 does not contain the developmental precursor of this macronuclear version of the $\mathrm{C} 3$ gene, but the precursor of a different form of C3. However, the other two macronuclear and micronuclear clones previously isolated (pMAC3 and

Figure 3. Sequences of the micronuclear and macronuclear Rl genes from clones LMICR $1-7$ and pMACRl. The sequence of the main body of the macronuclear R1 gene is shown in upper-case letters, and numbered positively from left to right. Not shown are 20 bp of $\mathrm{C}_{4} \mathrm{~A}_{4}$ repeats present at each end of the macronuclear gene in clone pMACRl. The sequence of the micronuclear Rl gene is identical except for the presence of five IESs, which are in lower-case letters and overlined, and not included in the numbering system. DNA sequences flanking the left and right ends of the R1 gene in the micronucleus are also shown in lower case, and numbered negatively proceeding from each end. 
A.
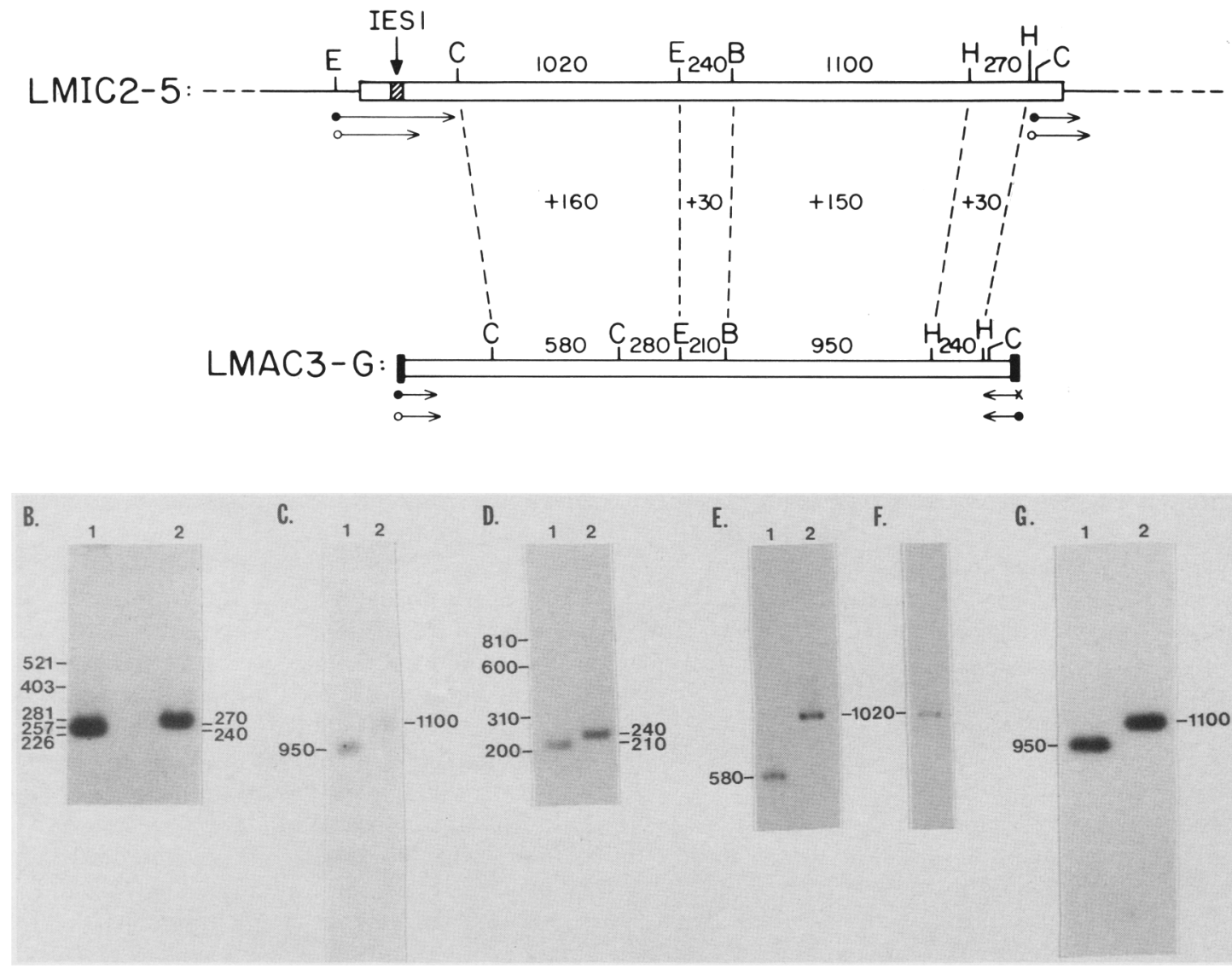

Figure 4. Macronuclear and micronuclear organization of the $\mathrm{C} 3$ gene. $(A)$ Restriction maps of the $\mathrm{C} 3$ gene in macronuclear clone LMAC3-G and the region of the micronuclear clone LMIC2-5 containing the micronuclear C3 gene (open box). (E) EcoRI; (C) HincII; (B) BamHI; (H) HindIII. Sizes of restriction fragments are given in base pairs. Terminal $\mathrm{C}_{4} \mathrm{~A}_{4}$ repeats are shown as black boxes and an IES detected by DNA sequence analysis is shown as a hatched box. Dashed lines indicate homologous restriction fragments in the two clones and their size differences (e.g., +30$)$. Regions sequenced are indicated by arrows: sequencing from $3^{\prime}(O)$ or $5^{\prime}(O)$ ends by the chemical method or sequencing by the dideoxy method $(\times) .(B)$ Hybridization of the 240-bp HindIII fragment of LMAC3-G to HindIIIdigested LMAC3-G DNA (lane 1) and HindIII-digested LMIC2-5 DNA (lane 2). (C) Hybridization of the 950-bp BamHI-HindIII fragment of LMAC3-G to BamHI + HindIII digests of LMAC3-G (lane 1) and LMIC2-5 (lane 2). (D) Hybridization of the 210-bp EcoRIBamHI fragment of LMAC3-G to EcoRI + BamHI digests of LMAC3-G (lane 1) and LMIC2-5 (lane 2). (E) Hybridization of the 580-bp HincII fragment of LMAC3-G to HincII + EcoRI digests of LMAC3-G (lane 1) and LMIC2-5 (lane 2). (F) Hybridization of the 280-bp HincII-EcoRI fragment of LMAC3-G to a HincII + EcoRI digest of LMIC2-5. (G) Hybridization of the 950-bp BamHI-HindIII fragment of LMAC3-G to BamHI + HindIII digests of $0.05 \mu \mathrm{g}$ of total macronuclear DNA (lane 1) and $1.0 \mu \mathrm{g}$ of total micronuclear DNA (lane 2). For $B-G$, sizes of homologous fragments are given in base pairs. In $B$ and $D$, positions of size standards are also indicated.

LMIC2-2, respectively; see Klobutcher et al. 1986), which again appear to be developmental cognates on the basis of partial DNA sequence analysis, also differ in this same HincII site (data not shown). We suggest that the HincII site is formed during the maturation of the macronuclear gene in conjunction with the removal of an IES. That is, an IES in the micronuclear copy of the C3 gene splits the HincII recognition sequence. This would represent a phenomenon complementary to that observed for the R1 gene, where EcoRI and Sau3A sites contained within IESs are lost from the macronuclear copy of the gene (Fig. 1). To prove that all micronuclear copies of the C3 gene contain IESs, and to rule out the possibility that the above data are simply the result of analyzing a clone of a nonprocessed micronuclear version of the $\mathrm{C} 3$ gene, a hybridization experiment to total macronuclear and micronuclear DNA was performed. The 950-bp BamHI-HindIII fragment of LMAC3-G was hybridized to total macronuclear DNA and total micronuclear DNA doubly digested with BamHI and HindIII. These enzymes were chosen because the relevant recognition sites for these enzymes are present in all cloned macronuclear and micronuclear copies of the $\mathrm{C} 3$ gene. All homologous macronuclear DNA fragments were $950 \mathrm{bp}$ long, while in total micronuclear DNA the corresponding fragments were $1100 \mathrm{bp}$ (Fig. 4G). Therefore, all micronuclear copies of the $\mathrm{C} 3$ gene contain extra DNA within this restriction fragment interval. 


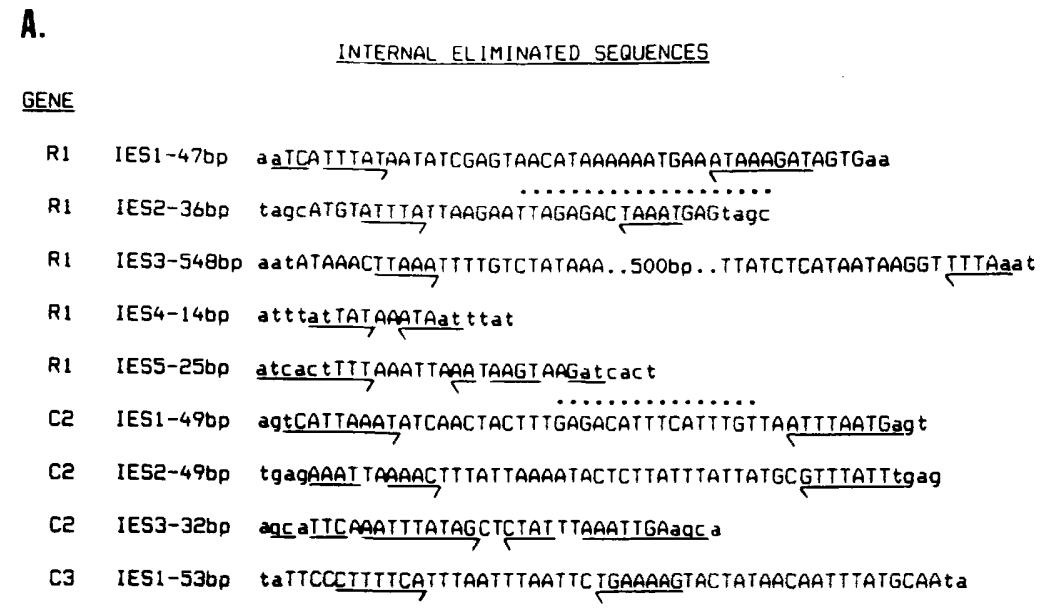

B.

CLASS 1

Ce IES 2

IERMINAL SEQUENCE HOMOLOGIES OF IESS

RI IES 3

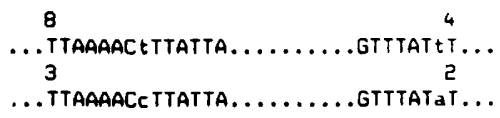

CLASS II

RI IES 1

R1 IES 2

RI IES 4

RI IES 5

C2 IES 3

CONSENSUS

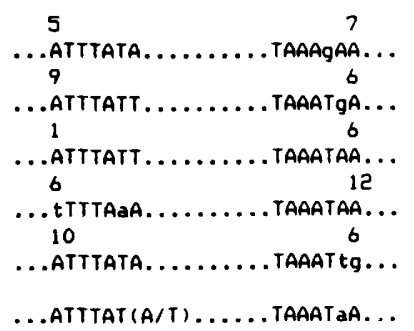

Figure 5. Sequences of IESs. (A) Sequences of the IESs in the micronuclear copies of the R1, C2, and C3 genes are shown. Only the terminal sequences of the large IES3 of the R1 gene are shown. The terminal direct repeats, one copy of which is retained in the macronuclear DNA molecule, are shown in lower case. Inverted repeats are underlined with interruptions denoting gaps or mismatches. Note that the stated sizes of the IESs refer to the number of bases eliminated, and do not include both copies of the direct repeat. Dots above R1-IES2 and C2-IES1 denote the regions of the IESs used to construct synthetic oligonucleotide hybridization probes. $|B|$ Conserved sequences near termini that allow IESs to be placed into two classes are shown. Numbers indicate distance of conserved sequence blocks from the first base of the direct repeat at each end. A consensus sequence for Class II IESs is also shown. For IES 3 of the R1 gene, the conserved sequences are present on the strand opposite to that shown in $A$. All sequences are displayed 5' to $3^{\prime}$.

Overall, the mapping studies define four intervals where the micronuclear copy of the $\mathrm{C} 3$ gene contains extra DNA sequences and a minimum of one IES. Including the 53-bp IES found during the sequencing of the C3 gene termini, at least five IESs must be present in the micronuclear copy of this gene.

\section{Sequence organization of IESs}

The DNA sequences of the IESs were compared for common features that might provide some insight into how their developmental removal is accomplished or into what function they might serve in the micronuclear genome. The DNA sequences of the five IESs of the micronuclear R1 gene and IES1 of the C3 gene are shown in Figure 5A. Also shown are the previously determined sequences of the three IESs in the micronuclear $\mathrm{C} 2$ gene of O. nova (Klobutcher et al. 1984). Two common organi- zational features that had been noted for the latter three IESs (Klobutcher et al. 1984) were also seen in the sequences of the six IESs of the R1 and C3 genes. First, each has a direct repeat of $2-6 \mathrm{bp}$ at its ends, and one copy of the direct repeat is maintained in the mature macronuclear DNA molecule after removal of the IES. Second, all of the IESs have short inverted repeats near their ends. Although some of the inverted repeats are short and imperfect, the long and perfect, or nearly perfect, inverted repeats of IES1 and IES4 of the R1 gene and IES1 and IES3 of the C2 gene (Fig. 5A) lead us to believe that such repeats constitute an important organizational feature of IESs.

Aside from being very AT-rich $175-100 \%$ AT base pairs), no significant stretches of primary sequence homology were found that are shared by all IESs. However, a number of IESs share some limited homology near 
their termini that can be used to define two classes of IESs. Class I IESs (IES2 of the C2 gene and IES3 of the R1 gene/ contain 14-bp and 8-bp regions of nearly identical sequences near their termini (Fig. 5B). Five of the other IESs fall into the second class, which is defined by the presence of the consensus sequences $5^{\prime}$-ATTTAT(A/T)$3^{\prime}$ and $5^{\prime}$-TAAATaA- ${ }^{\prime}$ within 20 bp of the ends of the IESs (Fig. 5B). It is noteworthy that the terminal consensus sequences of both classes have complementary regions, and usually form part of the inverted repeats present near the ends of the IESs. Although the conserved sequences that define the two classes of IESs are AT-rich, the length of the conserved elements and their subterminal localization make it unlikely that such similarities would be seen by chance alone, and suggest that these sequences may play a role in the developmental excision of IESs. The two remaining IESs, IES1 of the C2 gene and IES1 of the C3 gene, do not fit easily into either of the two classes, although their right ends contain sequences similar to the right element of class I IESs. They may represent entirely new classes of IESs, for which we have not yet encountered other members.

Finally, the IESs are not likely to code for proteins. Aside from their generally small sizes, they are all AT rich. The coding regions of all hypotrich macronuclear DNA molecules sequenced to date are composed of only 50-60\% AT base pairs (L. Klobutcher, unpubl.; G. Herrick, pers. comm.). Even the large 549-bp IES3 of the R1 gene does not contain any long open reading frames, nor does it contain regions that display a high $5^{\prime}$-RNY/YNR3 ' ratio, which has been found to correlate with true coding regions in a variety of organisms (Sheperd 1981).

\section{Copy number of IESs in the micronuclear genome}

A series of hybridization analyses were performed to determine if IESs represent unique or repetitive sequences in the micronuclear genome. Determining the frequency of the small IESs in the micronuclear genome through conventional Southern hybridization analysis proved to be technically difficult because of their small size and AT-richness. However, it was possible to obtain a measure of the repetition of IESs by synthesizing oligonucleotides complementary to the small IESs and using them to probe an $O$. nova genomic micronuclear DNA library (LMIC library; Klobutcher et al. 1984).

A 20-base oligonucleotide complementary to IES2 of the micronuclear Rl gene (see Fig. 5A) was synthesized for use as a hybridization probe. Specific hybridization conditions were first empirically determined by hybridizing the IES2 oligonucleotide, radiolabeled with ${ }^{32} \mathrm{P}$, to Southern blots containing the 900-bp EcoRI fragment of LMICR1-7 (which contains IES2) and washing the blots at different temperatures under conditions described by Wood et al. (1985). A strong hybridization signal was observed when the blot was washed at $56^{\circ} \mathrm{C}$, but the hybridization signal decreased when a duplicate filter was washed at $61^{\circ} \mathrm{C}$ (data not shown). The decrease in the hybridization signal at $61^{\circ} \mathrm{C}$ agreed well with the predicted disassociation temperature of $60^{\circ} \mathrm{C}$, based on the data of Wood et al. (1985). Thus, in subsequent hybrid- izations, filters were washed at $56^{\circ} \mathrm{C}$ to detect specifically sequences homologous to IES2 of the R1 gene.

The R1 IES2 oligonucleotide probe was then used to screen 60,000 recombinant micronuclear clones. As the average size of the micronuclear insert in a single recombinant clone is approximately $12 \mathrm{kbp}$, screening 60,000 clones is equivalent to examining $7.2 \times 10^{8} \mathrm{bp}$ of $\mathrm{mi}$ cronuclear DNA. This is roughly equivalent to the haploid DNA content of the micronucleus $\left(6.2 \times 10^{8} \mathrm{bp}\right.$; Lauth et al. 1976). Six of the 60,000 recombinant clones hybridized with the R1 IES2 oligonucleotide probe (Table 1). The filters containing the recombinant clones were then stripped of the oligonucleotide probe and rehybridized with the 493-bp PVuII-PstI fragment of pMACR1. The same six recombinant clones shared homology with the second probe (Table 1), indicating that sequences homologous to IES2 are found only in the context of the Rl gene in the micronuclear genome. Although the detection of six recombinant clones is somewhat higher than expected for a unique sequence in the micronuclear genome, data presented below indicate that the R1 gene is present in only two copies in the diploid micronuclear genome. Thus, IES2 is unique, or at most present in a few copies, in the micronuclear genome.

Similar experiments were done to determine the degree of repetition of IES1 of the C2 gene. A 16-base oligonucleotide complementary to IES1 of the $\mathrm{C} 2$ gene was synthesized (see Fig. 5A) and used to screen 45,000 recombinant micronuclear clones. Three recombinant clones hybridized with the IES1 probe (Table 1). When the macronuclear $\mathrm{C} 2$ gene clone pMAC2 (Klobutcher et al. 1984) was used to screen a duplicate set of plaque lifts, the same three clones were detected, plus one additional clone (Table 1). Again, these results indicate that the IES is present in few copies in the micronuclear genome and only in the context of the $\mathrm{C} 2$ gene. The single clone that hybridized with pMAC2, but not with the IES 1 probe, may have been a false positive, or it may contain an incomplete $\mathrm{C} 2$ gene lacking the region containing IES1.

The large size of the 548-bp IES3 of the R1 gene made it possible to use a restriction fragment derived from this IES to probe directly Southern blots containing micronuclear DNA to determine copy number. When the 250-

Table 1. Screening of micronuclear library with IES oligonucleotide probes

\begin{tabular}{|c|c|c|}
\hline $\begin{array}{l}\text { Hybridization } \\
\text { probe }\end{array}$ & $\begin{array}{l}\text { Number of } \\
\text { recombinant } \\
\text { plaques } \\
\text { screened }\end{array}$ & $\begin{array}{l}\text { Number of } \\
\text { homologous } \\
\text { plaques } \\
\text { detected }\end{array}$ \\
\hline $\begin{array}{l}\text { R1-IES2: } 20 \mathrm{~b} \\
\text { oligonucleotide }\end{array}$ & 60,000 & 6 \\
\hline $\begin{array}{l}\text { MAC. R1 gene: } 493-b p \\
\text { PvuII-PstI }\end{array}$ & 60,000 & 6 \\
\hline $\begin{array}{l}\text { C2-IES1: } 16 \mathrm{~b} \\
\text { oligonucleotide }\end{array}$ & 45,000 & 3 \\
\hline $\begin{array}{l}\text { MAC. C2 gene-clone } \\
\text { pMAC2 }\end{array}$ & 45,000 & 4 \\
\hline
\end{tabular}


bp EcoRI-Sau3A fragment derived from IES3 (Fig. 1) was hybridized to HindIII-digested micronuclear DNA, and the filter was washed under stringent conditions, homology to restriction fragments of 4.6 and $2.3 \mathrm{kbp}$ was detected (Fig. 6A; the third higher-molecular-weight band seen in the hybridization represents a partial digestion product, as it was not seen in repeats of this hybridization, nor in the low-stringency hybridization shown in Fig. 6B). The 4.6-kbp fragment corresponds to the expected micronuclear fragment based on the restriction map of LMICR1-7 (Fig. 1), while the 2.3-kbp fragment represents the previously detected second variant form of the R1 gene in the micronucleus (Fig. 2B). Thus, IES3 also exists only in the context of the two forms of the R 1 gene in the micronucleus. Furthermore, each of these micronuclear copies appears to be present only once per micronuclear genome, as is evident from comparisons of the hybridization signals in micronuclear DNA to those obtained with known amounts of HindIII-digested LMICR 1-7 DNA representing 1, 10, and 100 copies per diploid genome (Fig. 6A, lanes 2-4). Finally, no hybridization to macronuclear DNA was detected, consistent with IES3 being eliminated from the genome during macronuclear development (Fig. 6A, lane 5).

A similar hybridization was done under low-stringency conditions to determine if there were micronuclear sequences related to, but not identical to, IES3 of the $\mathrm{Rl}$ gene. In this case the blot was washed at $50^{\circ} \mathrm{C}$ in $2 \times$ SSC. These wash conditions were calculated to be about $30^{\circ} \mathrm{C}$ below the $T_{m}$ of the probe, thus allowing DNA fragments with about $30 \%$ mismatching to be detected (Bonner et al. 1973). Even under these conditions, only hybridization to the 4.6- and 2.3-kbp HindIII fragments was seen (Fig. 6B), again indicating that IES3 sequences are unique in the micronucleus.

\section{Discussion}

\section{Frequency of IESs in the micronuclear genome}

By DNA sequence analysis, five IESs have been found in the micronuclear precursor of the $1.05-\mathrm{kbp}$ macronuclear R1 gene. Through hybridization and sequence analyses, five or more IESs were also found in the precursor of the 2.85-kbp macronuclear C3 gene. Previously, we had found that three IESs exist in the micronuclear copy of the $0.81 \mathrm{kbp}$ macronuclear $\mathrm{C} 2$ gene (Klobutcher et al. 1984). Thus, it appears that IESs, and hence nucleic acid splicing events during macronuclear development, are very common in the hypotrichous ciliated protozoa. If we extrapolate from our results on these three genes, and consider that 20,000 different DNA molecules exist in the macronucleus (Lauth et al. 1976), we estimate that greater than 60,000 IESs are removed during the course of macronuclear development in O. nova. Although this estimate should be considered tenative, as it is based on the analysis of only three genes, there is some reason to believe it may be accurate. The above three macronuclear DNA molecules are the only ones whose micronuclear organization has been examined in detail. There are no cases in O. nova, nor in any other hypotrich species, where the micronuclear copy of a gene has been found to lack IESs. IESs have been found in the micronuclear precursors of a macronuclear gene family of $O$. fallax (G. Herrick, pers. comm.). Similarly, some evidence exists for an IES in a gene of Stylonychia pustulata (Oka and Honjo 1983), although in this instance the micronuclear and macronuclear clones studied appeared to be derived from different forms of the gene analyzed, so that their precursor-product nature is in doubt. In addition, developmental removal of DNA sequences by nucleic acid splicing has also been

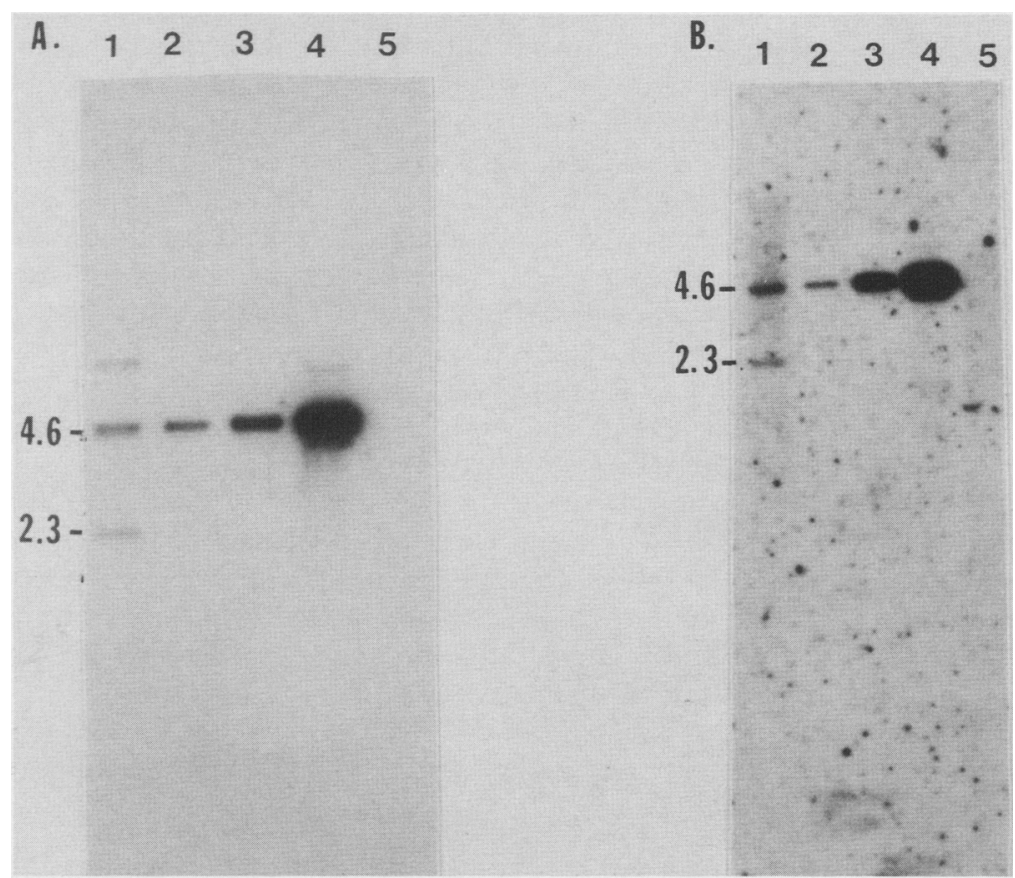

Figure 6. (A) Autoradiograph of hybridization of the 250-bp EcoRI-Sau3A fragment of IES3 of the micronuclear R1 gene to a Southern blot containing: (lane 1) $1.0 \mu \mathrm{g}$ of HindIII-digested micronuclear DNA; (lane 2) $5 \times 10^{-5} \mu \mathrm{g}$ HindIII-digested LMICR1-7; (lane 3) $5 \times 10^{-4} \mu \mathrm{g}$ HindIII LMICR1-7; (lane 4) $5 \times 10^{-3} \mu \mathrm{g}$ HindIII LMICR 1-7; (lane 5) 0.05 $\mu \mathrm{g}$ of native macronuclear DNA. The amounts of HindIII-digested LMICR 1-7 DNA in lanes 2-4 were chosen to represent 1,10 , and 100 copies, respectively, of a sequence per diploid micronuclear genome, relative to the amount of DNA in lane 1. Hybridization and washes were performed at $60^{\circ} \mathrm{C}$. Sizes of homologous fragments are indicated in $\mathrm{kbp}$. (B) Hybridization of the 250-bp EcoRI-Sau3A fragment of IES3 of the R1 gene to a Southern blot constructed as in $A$, except that hybridization and washes were performed at $50^{\circ} \mathrm{C}$, and $2 \times$ SSC was used as the wash solution. 
found to occur frequently in the holotrichous ciliated protozoan Tetrahymena thermophila (Callahan et al. 1984; Yao et al. 1984). Although the sizes of the eliminated sequences in Tetrahymena are much larger than IESs, this almost certainly represents an analogous process, and one that may be common to all ciliated protozoa.

All of the IESs that have been sequenced are, with the exception of the 548-bp IES3 of the R1 gene, less than 60 bp in length. They are each bounded by a short direct repeat of 2-6 bp and possess a short stretch of inverted nucleotides near their termini. No primary sequence features common to all IESs are evident. We have, however, defined two classes of IESs based on short terminal sequence homologies. Additional classes of IESs may exist, as two of the IESs considered in this study do not fit into the described classes. It is unlikely that larger regions of homology exist between IESs in different macronuclear gene precursors. Hybridization analyses carried out with three of the IESs clearly indicate that they are unique within the micronuclear genome and exist only in the context of the respective macronuclear gene precursors. This conclusion is strongest for IES3 of the Rl gene, where even under nonstringent hybridization conditions, no additional homologous micronuclear sequences were detected.

\section{Possible functions of IESs}

Despite their frequent occurrence, the function of IESs is unknown. We, and others, have speculated that IESs may have a role in specifying the functional differences that exist between the macronucleus and micronucleus (Callahan et al. 1984; Klobutcher et al. 1984; Yao et al. 1984). In particular, IESs might be involved in the lack of gene expression in the micronucleus or the transcriptional activation of genes that occurs during macronuclear development. Precedents for the involvement of developmental DNA elimination events in the regulation of gene expression include the immunoglobulin and $\mathrm{T}$-cell receptor genes in the vertebrate immune system (Hood et al. 1985), and the nitrogen fixation genes in the cyanobacterium Anabaena (Haselkorn et al. 1986). In each of these instances, elimination of DNA is required to juxtapose coding regions, thus allowing the synthesis of the relevant protein products. We have previously noted that IES1 of the $\mathrm{C} 2$ gene interrupts the coding region of this macronuclear DNA molecule /Klobutcher et al. 1984). This IES also introduces an in-frame termination codon into the $\mathrm{C} 2$ gene, making it impossible to produce the proper gene product in the micronucleus. A similar situation probably exists for the Rl gene. Although we do not know the function of this macronuclear DNA molecule, nor have we been able to detect a homologous transcript in Northern blotting experiments, a long open reading frame occurs within this macronuclear DNA molecule. The open reading frame exists on the opposite strand of the gene as it is shown in Figure 3, beginning at base 922 and ending at base 41 . This open reading frame is based on the nonstandard genetic code of ciliated protozoa, where the normal termi- nation codons TAA and TAG both appear to code for amino acids (Helftenbein 1985; Preer et al. 1985). Additional evidence that this region represents a true reading frame includes: (1) it contains $59 \%$ AT base pairs, similar to the coding regions of other hypotrich genes ( $\mathrm{L}$. Klobutcher, unpubl.; G. Herrick, pers. comm.), (2) it displays an elevated RNY/YNR ratio, indicative of coding regions in many organisms (Sheperd 1981), and (3) it displays a bias in codon usage similar to that observed in other hypotrich genes, although it should be noted that only the $\mathrm{C} 2$ gene of $O$. nova (Klobutcher et al. 1984), the actin gene of O. fallax (Kaine and Spear 1982), and the tubulin gene of S. mytilus (Helftenbein 1985) are available for comparison. If this reading frame is utilized, all five of the IESs would reside within it in the micronucleus and introduce numerous translation termination codons.

Aside from interrupting coding regions, IESs could exert more general effects on transcription. IESs might serve as binding sights for proteins that repress transcription in the micronucleus or generally alter the conformation of the DNA or chromatin so as to make it inaccessible to transcription. Alternatively, IESs might split positive transcriptional control elements in the micronuclear copies of genes, such that they only become active following the excision of IESs during development.

An alternative view is that IESs serve no function in the micronucleus. They are simply tolerated in the micronucleus because the micronuclear genes are transcriptionally inactive, and because a mechanism exists for their removal during the formation of a transcriptionally active genome. Under this view, IESs would essentially be a form of "selfish DNA" (Doolittle and Sapienza 1980; Orgel and Crick 1980). It is interesting that IESs organizationally resemble one type of DNA that has been suggested to be selfish-transposable elements. Many transposable elements possess inverted repeats at their termini that are required for transposition, and also create a short DNA duplication at their sites of integration (Kleckner 1981; Finnegan 1985). The IESs are similarly arranged, with the terminal direct repeats being analogous to the target site duplication. It is clear, however, that IESs are not bona fide transposable elements. Transposable elements generally code for proteins involved in the transposition process. Most of the IESs detected are too small to code for proteins, and the large 548-bp IES3 of the R1 gene contains no significant open reading frames. A second difference is that IESs are precisely removed as part of a developinental process, while transposable elements usually transpose or excise in a random manner. There are, however, two instances where the movement of transposable elements displays a degree of developmental and tissue specificity. The $\mathrm{P}$ elements of Drosophila melanogaster become highly mobile following fertilization in crosses between particular strains (Rubin et al. 1982), and a transposable element in the nematode Caenorhabditis elegans excises at a much higher rate in somatic cells than in the germ line (Emmons and Yesner 1984). 
An intriguing possibility is that IESs are related to true transposable elements present elsewhere in the micronuclear genome that become active during macronuclear development and effect IES removal. IESs would be similar to defective elements observed in other eukaryotes (e.g., Federoff et al. 1983) that have lost the ability to code for transposition functions, but have retained the DNA sequence information required for precise excision. The intact elements would provide the required transposition proteins in trans. Part of the impetus for determining the copy number of IESs in the micronuclear genome was to test this hypothesis. The observed lack of additional sequences homologous to IESs in the micronuclear genome makes it unlikely that IESs are closely related to transposable elements. However, it is not possible to dismiss completely this hypothesis. Perhaps only short stretches of homology, not detectable by hybridization, are required for recognition by transacting excision proteins. For instance, the short terminal sequence similarities noted among IESs (Fig. $5 \mathrm{~B}$ ) might be sufficient to signal excision, but would not have been detected in our hybridization analyses. The fact that IES4 of the R1 gene is only 14 bp long suggests that little sequence information is required for IES excision. Additional information on both the sequence requirements for IES excision and on transposable elements in the micronuclear genome will be required to determine if IES removal is transposon related. To date, only one putative transposable element has been described in the hy- potrich O. fallax (Herrick et al. 1985). Interestingly, a copy of this element resides in micronuclear sequences homologous to a macronuclear gene, although it has not yet been demonstrated that this micronuclear locus is processed during development and that the transposon is excised (i.e., other micronuclear copies of the macronuclear gene exist that lack the putative transposon).

\section{Models of IES excision}

The structures of IESs suggest a number of models for their developmental excision. Four possible models are shown in Figure 7. In model 1, the IES forms a loop such that the terminal repeats become aligned. A recombination event between bases in the direct repeats would then liberate the IES and leave the macronuclear gene precursor with a single copy of the direct repeat. In its simplest form, this type of mechanism seems unlikely. The small sizes of most IESs, and the stiffness of the DNA helix, would prohibit the required looping for alignment of the direct repeats.

Models 2 and 3, therefore, propose single-stranded looping out of IES DNA as a means of bringing the direct repeats at opposite ends into alignment (similar models have been proposed to explain spontaneous deletion events; see Efstratiadis et al. 1980; Albertini et al. 1982). In model 2 , the IES would then be removed by a recombination event between the direct repeats. Alternatively, such misaligned sequences resemble substrates for DNA repair enzymes and might be removed by a similar

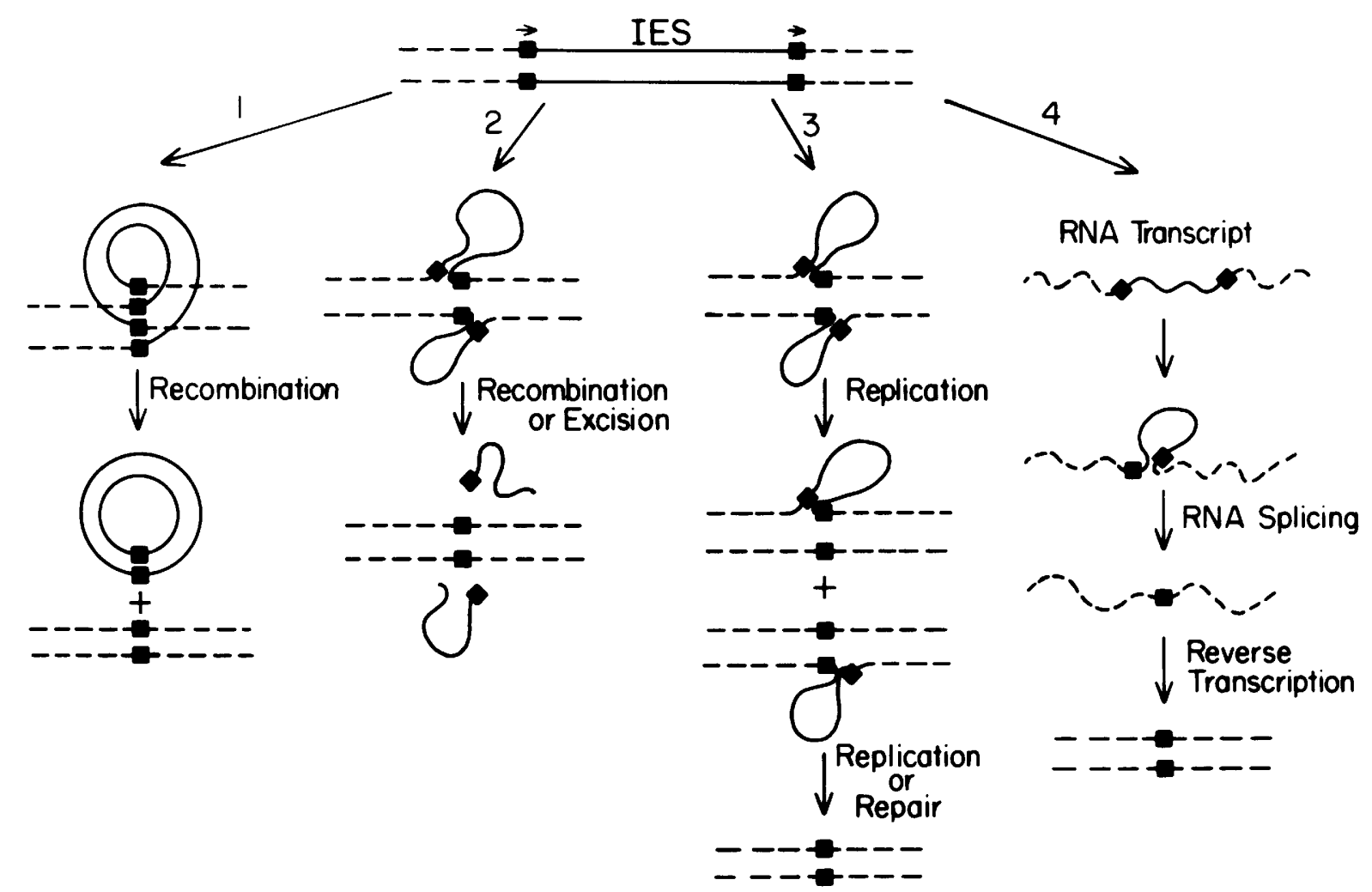

Figure 7. Four models for the developmental excision of IESs from the micronuclear copies of macronuclear DNA molecules. The IES is shown as a solid black line with the terminal direct repeats indicated as black boxes. Flanking DNA sequences destined to form part of the macronuclear DNA molecule are shown as dashed lines. The models are described in the text. 
system. Model 3 does not require excision of the IES per se. Instead, DNA replication proceeds through the misaligned DNA duplex, generating two daughter heteroduplex molecules with one strand lacking the IES. A second round of replication would then produce a DNA molecule completely lacking the IES, and subsequent rounds of DNA replication would continue to dilute out the strands containing the IES. Alternatively, the heteroduplexes might be subject to repair processes that actively eliminate the IES. The involvement of DNA replication in IES removal is plausible, as replication occurs both during the formation of polytene chromosomes and the late stages of macronuclear development (Prescott 1983; Ammermann et al. 1974). Furthermore, two features of IESs might favor the formation of the singlestranded loops required in both models 2 and 3 . The AT richness of IESs would presumably aid in the denaturation of the DNA and the subterminal inverted repeats would help stabilize the loops and bring the direct repeats into alignment. The latter process might be aided by proteins that bind to the conserved sequences noted within the inverted repeats (Fig. $5 \mathrm{~B}$ ).

Model 4 suggests that the macronuclear gene precursor is first transcribed in its entirety and then the IES is removed by an RNA splicing process. As a final step, the processed RNA is converted back to DNA by reverse transcription. It is difficult to evaluate the plausibility of this model, as the literature contains conflicting reports as to whether transcription occurs in the developing macronucleus (Ammermann 1968; Alonso and Jareno 1974). However, in support of this model, Lipps (1985) has noted that there is a dramatic rise in reverse transcriptase activity during macronuclear development. The model is also attractive in that transcription provides a means of "excising" the macronuclear gene precursor from the chromosome. Analysis of the nature of transcripts produced during macronuclear development, if any, would provide a clear indication as to whether this model merits consideration.

Finally, it might be asked whether a phenomenon analogous to IES removal occurs in the somatic cells of higher eukaryotes. IESs do not appear to interrupt the coding sequences of genes that are expressed in a tissuespecific manner. Many such genes have been cloned and analyzed from DNA isolated from the entire organism, as opposed to the tissue where they are expressed, and found to contain intact coding regions interrupted only by introns. Whether IESs exist in the vicinity of developmentally expressed genes is less clear. Some comparisons between DNA in the germ line and soma of multicellular eukaryotes have been done (e.g., Emmons et al. 1979) and no differences in the organization of genes were detected. However, most such comparisons have been at the level of crude restriction mapping. DNA rearrangement events involving an element the size of an IES clearly require fine-structure restriction mapping or DNA sequence analysis to be detected. To our knowledge, no studies have been done at this level of resolution. If IESs prove to play a role in the regulation of transcription in hypotrichs, they provide an attractive means of stably regulating the developmental expression of genes in other organisms.

\section{Materials and methods}

Cell culture and DNA isolation

Culturing of $\mathrm{O}$. nova, strain $\mathrm{H} 10$, using the alga Chlorogonium as a food source, was performed as described previously (Swanton et al. 1980a). Isolation of macronuclei and micronuclei from starved cells and purification of DNAs were done as described (Lauth et al. 1976; Klobutcher et al. 1984), with the following modification. As a final step, micronuclear DNA was submitted to differential centrifugation through a $5-20 \%$ potassium acetate gradient (Maniatis et al. 1982) to remove any contaminating macronuclear DNA.

Bacterial plasmid DNA and replicative forms of the recombinant M13 phage were prepared using either the SDS-lysis or the alkaline-lysis procedures (Godson and Vapnek 1973; Maniatis et al. 1982). Recombinant bacteriophage clones were purified on glycerol step gradients and DNA prepared as described (Maniatis et al. 1982).

\section{Recombinant libraries and clones}

The construction of the O. nova macronuclear and micronuclear recombinant DNA libraries used in these studies has been described (Klobutcher et al. 1984). Bacteriophage $\lambda$ libraries were screened using the method of Benton and Davis (1977).

The isolation of the recombinant macronuclear and micronuclear clones of the $\mathrm{Rl}$ and $\mathrm{C} 3$ genes used in these studies has been described previously (Klobutcher et al. 1986).

\section{Restriction mapping and DNA sequencing}

Restriction endonucleases and other modifying enzymes were purchased from either Bethesda Research Laboratories or New England Bio-Labs, Inc., and were used according to the manufacturers' directions.

To deduce the restriction maps of recombinant clones, they were singly or doubly digested with restriction endonucleases and the digests were analyzed by electrophoresis on $0.75-1.5 \%$ agarose or low-melting-point agarose gels. In some cases, subcloning of specific restriction fragments into the plasmid vectors pBR322 and pBR325 was carried out to facilitate the manipulation and study of the DNA sequences.

DNA sequencing was performed by the Maxam and Gilbert (1980) chemical method with minor modifications (Klobutcher et al. 1981). Additional sequence information was obtained by subcloning DNA fragments into bacteriophage M13 mp8, mp9, mpl0, or mpl1, and sequencing by the dideoxy chain-termination method (Sanger et al. 1977).

\section{DNA labeling and hybridization}

DNA probes were labeled with $\left[a^{-32} \mathrm{P}\right] \mathrm{dATP}$ by nick-translation (Rigby et al. 1977) or with the Klenow fragment of DNA polymerase I using random oligonucleotides as primers (Feinberg and Vogelstein 1983, 1984).

DNA was transferred from agarose gels to nitrocellulose or Gene Screen Plus (New England Nuclear) filters as described by Southern (1975). The filters were hybridized with radioactive probes at $65^{\circ} \mathrm{C}$ under conditions described previously (Boswell et al. 1982). Unless otherwise noted, filters received two 30-min washes at $65^{\circ} \mathrm{C}$ in $2 \times \operatorname{SSC}(1 \times \mathrm{SSC}=0.15 \mathrm{M} \mathrm{NaCl}, 0.015 \mathrm{M}$ Na-citrate, $\mathrm{pH} 7.0$ ) plus $0.5 \%$ SDS, followed by two $30-\mathrm{min}$ 
washes at $65^{\circ} \mathrm{C}$ in $0.1 \times$ SSC plus $0.5 \%$ SDS. To ensure that restriction endonuclease digestions of macronuclear DNA proceeded to completion, $\lambda$ gt 10 DNA was added to the reaction as an internal control. An aliquot of each restricted DNA sample was then run on an agarose gel, Southern blotted, and the blot hybridized with nick-translated $\lambda$ gt 10 to confirm the completion of the digest.

\section{Oligonucleotide screening of $\lambda$ recombinant libraries}

The deoxyoligonucleotides used as hybridization probes and/or primers for the dideoxy sequencing were synthesized on a Systec model 1450 A synthesizer. For hybridization, oligonucleotides were $5^{\prime}$-end labeled with $\left[\gamma^{-32} \mathrm{P}\right]$ ATP and T4 polynucleotide kinase (Maniatis et al. 1982). Hybridizations were done at $37^{\circ} \mathrm{C}$ for $18-20 \mathrm{hr}$ as described previously (Boswell et al. 1982).

Following hybridization, filters hybridized with the 20-base oligonucleotide complementary to IES 2 of the micronuclear R1 gene (see text) were washed as described by Wood et al. (1985). This entailed three rinses with $6 \times \mathrm{SSC}$ at $4^{\circ} \mathrm{C}$, followed by two 30 -min washes with $6 \times \operatorname{SSC}$ at $4^{\circ} \mathrm{C}$. Finally, the filters received two $20-\mathrm{min}$ washes at $56^{\circ} \mathrm{C}$ in a solution containing $3.0 \mathrm{M}$ tetramethylammonium chloride, $50 \mathrm{mM}$ Tris- $\mathrm{Cl}(\mathrm{pH} 8.0), 2 \mathrm{~mm}$ EDTA, and $1 \mathrm{mg} / \mathrm{ml}$ SDS.

Filters hybridized with the 16-base oligonucleotide complementary to IES1 of the micronuclear C2 gene (see text) were washed for $1 \mathrm{hr}$ at $37^{\circ} \mathrm{C}$ in $6 \times \mathrm{SSC}$, followed by a second 1 -hr wash in $6 \times \mathrm{SSC}$ at $42^{\circ} \mathrm{C}$.

\section{Acknowledgments}

We wish to thank Dr. Ann Cowan, Ms. Lori Tausta, and Mr. Scott Baird for their helpful comments on the manuscript. This work was supported by Public Health Service grant GM-33277 and March of Dimes Basil O'Connor Starter Research Grant 5-460 to L.A.K.

\section{Note}

Sequence data described in this paper have been submitted to the EMBL/GenBank Data Libraries under the accession number Y00207.

\section{References}

Albertini, A.M., M. Hofer, M.P. Calos, and J.H. Miller. 1982. On the formation of spontaneous deletions: The importance of short sequence homologies in the generation of large deletions. Cell 29: 319-328.

Alonso, P. and A. Jareno. 1974. Incorporacion de uridina- $\mathrm{H}^{3}$ en el esbozo macronuclear de Stylonychia mytilus. Microbiol. Espan. 27: 199-211.

Ammermann, D. 1968. Synthese und Abbau der Nucleinsauren wahrend der Entwicklung des Makronucleus von Stylony. chia mytilus (Protozoa, Ciliata). Chromosoma 25: 107-120.

Ammermann, D., G. Steinbruck, L. von Berger, and W. Henning. 1974. The development of the macronucleus in the ciliated protozoan Stylonychia mytilus. Chromosoma 45: 401-429.

Beermann, S. 1977. The diminution of heterochromatic chromosomal segments in Cyclops (Crustacea, Copepoda). Chromosoma 60: 297-344.
Benton, W.D. and R.W. Davis. 1977. Screening recombinant clones by hybridization to single plaques in situ. Science 196: $180-182$.

Bonner, T.I., D.J. Brenner, B.R. Neufeld, and R.J. Britten. 1973. Reduction in the rate of DNA reassociation by sequence divergence. I. Mol. Biol. 81: 123-135.

Boswell, R.E., L.A. Klobutcher, and D.M. Prescott. 1982. Inverted terminal repeats are added to genes during macronuclear development in Oxytricha nova. Proc. Natl. Acad. Sci. 79: 3255-3259.

Boveri, T. 1899. Die entwicklung von Ascaris megalocephala unter lesonderer Berucksichtigung der Kernverhaltnisse. Festschritt Fur C. V. Kupffer, Jena, 1899, p. 383.

Brunn, A. and K. Kalthoff. 1983. Photoreversible inhibition by ultraviolet light of germ line development in Smittia sp. (Chironimidae, Diptera). Dev. Biol. 100: 426-439.

Callahan, R.C., G. Shalke, and M.A. Gorovsky. 1984. Developmental rearrangements associated with a single type of expressed $\alpha$-tubulin gene in Tetrahymena. Cell 36: 441-445.

Cartinhour, S.W. and G.A. Herrick. 1984. Three different macronuclear DNAs in Oxytricha fallax share a common sequence block. Mol. Cell. Biol. 4: 931-938.

Dawson, D. and G. Herrick. 1984. Rare internal $\mathrm{C}_{4} \mathrm{~A}_{4}$ repeats in the micronuclear genome of Oxytricha fallax. Mol. Cell. Biol. 4: 2661-2667.

Doolittle, W.F. and C. Sapienza. 1980. Selfish genes, the phenotype paradigm and genome evolution. Nature 284: 601-603.

Efstradiatis, A., J. Posakony, T. Maniatis, R. Lawn, C. O'Connell, R. Spritz, J. DeRiel, B. Forget, S. Weissman, J. Slightom, A. Blechl, O. Smithies, F. Baralle, C. Sholders, and N. Proudfoot. 1980. The structure and evolution of human $\beta$ globin gene family. Cell 21: 653-668.

Emmons, S.W. and L. Yesner. 1984. High-frequency excision of transposable element $\mathrm{Tcl}$ in the nematode Caenorhabditis elegans is limited to somatic cells. Cell 36: 599-605.

Emmons, S.W., M.R. Klass, and D. Hirsh. 1979. Analysis of the constancy of DNA sequences during development and evolution of the nematode Caenorhabditis elegans. Proc. Natl. Acad. Sci. 76: 1333-1337.

Federoff, N., S. Wessler, and M. Shure. 1983. Isolation of the transposable maize controlling elements Ac and Ds. Cell 35: 235-242.

Feinberg, A.P. and B. Vogelstein. 1983. A technique for radiolabeling DNA restriction endonuclease fragments to high specific activity. Analyt. Biochem. 132: 6-13.

- 1984. Addendum-A technique for radiolabeling DNA restriction fragments to high specific activity. Analyt. Biochem. 137: 266-267.

Finnegan, D.J. 1985. Transposable elements in eukaryotes. Int. Rev. Cytol. 93: 281-326.

Godson, G.N. and D. Vapnek. 1973. A simple method of preparing large amounts of $\phi \times 174$ RFI supercoiled DNA. Biochem. Biophys. Acta 299: 516-520.

Golden, J.W., S.J. Robinson, and R. Haselkorn. 1985. Rearrangement of nitrogen fixation genes during heterocyst differentiation in the cyanobacterium Anabaena. Nature 314: 419423.

Haselkorn, R., J.W. Golden, P.J. Lammers, and M.E. Mulligan. 1986. Developmental rearrangement of cyanobacterial nitrogen-fixation genes. Trends Genet. 2: 255-259.

Helftenbein, E. 1985. Nucleotide sequence of a macronuclear DNA molecule coding for $\alpha$-tubulin from the ciliate Stylonychia lemnae. Special codon usage: TAA is not a termination codon. Nucleic Acids Res. 13: 415-433.

Herrick, G., S. Cartinhour, D. Dawson, D. Ang, R. Sheets, A. Lee, and K. Williams. 1985. Mobile elements bounded by 
$\mathrm{C}_{4} \mathrm{~A}_{4}$ telomeric repeats in Oxytricha fallax. Cell 43: 759768.

Hood, L., M. Kronenberg, and T. Hunkapiller. 1985. T-cell antigen receptors and the immunoglobulin supergene family. Cell 40: 225-229.

Kaine, B.P. and B.B. Spear. 1982. Nucleotide sequence of a macronuclear gene for actin in Oxytricha fallax. Nature 295: 430-432.

Kleckner, N. 1981. Transposable elements in prokaryotes. Annu. Rev. Genet. 15: 341-404.

Klobutcher, L.A., M.T. Swanton, P. Donini, and D.M. Prescott. 1981. All gene-sized DNA molecules in four species of hypotrichs have the same terminal sequence and an unusual $3^{\prime}$ terminus. Proc. Natl. Acad. Sci. 78: 3015-3019.

Klobutcher, L.A., C.L. Jahn, and D.M. Prescott. 1984. Internal sequences are eliminated from genes during macronuclear development in the ciliated protozoan Oxytricha nova. Cell 36: 1045-1055.

Klobutcher, L.A., A.M. Vailonis-Walsh, K. Cahill, and R.M. Ribas-Aparicio. 1986. Gene-sized macronuclear DNA molecules are clustered in the micronuclear chromosomes of the ciliate Oxytricha nova. Mol. Cell. Biol. 6: 3606-3613.

Lauth, M.R., B.B. Spear, J. Heumann, and D.M. Prescott. 1976. DNA of ciliated protozoa: DNA sequence diminuition during macronuclear development of Oxytricha. Cell 7: $67-74$.

Lipps, H.J. 1985. A reverse transcriptase like enzyme in the developing macronucleus of the hypotrichous ciliate Stylonychia. Curr. Genet. 10: 239-243.

Maniatis, T., E.F. Fritsch, and J. Sambrook. 1982. Molecular cloning: A laboratory manual. Cold Spring Harbor Laboratory, Cold Spring Harbor, New York.

Maxam, A.M. and W. Gilbert. 1980. Sequencing end-labeled DNA with base-specific chemical cleavages. Methods Enzymol. 65: 499-560.

Metz, C.W. 1938. Chromosome behavior, inheritance, and sex determination in Sciara. Am. Nat. 72: 485-520.

Nock, A. 1981. RNA and macronuclear transcription in the ciliate Stylonychia mytilus. Chromosoma 83: 209-220.

Oka, Y. and T. Honjo. 1983. Common terminal repeats of macronuclear DNA are absent from the micronuclear DNA in hypotrichous ciliate, Stylonychia pustulata. Nucleic Acids Res. 11: 4325-4333.

Oka, Y., S. Shiota, S. Nakai, Y. Nishida, and S. Okubo. 1980. Inverted terminal repeat sequence in the macronuclear DNA of Stylonychia pustulata. Gene 10: 301-306.

Orgel, L.E. and F.H.C. Crick, 1980. Selfish DNA: The ultimate parasite. Nature 284: 604-607.

Pluta, A.F., B.P. Kaine, and B.B. Spear. 1982. The terminal organization of macronuclear DNA in Oxytricha fallax. Nucleic Acids Res. 10: 8145-8154.

Pluta, A.F., G.M. Dani, B.B. Spear, and V.A. Zakian. 1984. Elaboration of telomeres in yeast: Recognition and modification of termini from Oxytricha macronuclear DNA. Proc. Natl. Acad. Sci. 81: 1475-1479.

Preer, J.R., L.B. Preer, B.M. Rudman, and A.T. Barnett. 1985. Deviation from the universal code shown by the gene for surface protein 51A in Paramecium. Nature 314: 188-191.

Prescott, D.M. 1983. The C value paradox and genes in ciliated protozoa. Modern Cell Biol. 2: 329-352.

Rigby, P.W.J., M. Diekmann, C. Rhodes, and P. Berg. 1977. Labeling deoxyribonucleic acid to high specific activity in vitro by nick translation with DNA polymerase I. $J$. Mol. Biol. 113: $237-251$.

Roth, G.E. and K.B. Moritz. 1981. Restriction enzyme analysis of the germ line limited DNA of Ascaris suum. Chromosoma 83: 169-190.
Roth, M., M. Lin, and D.M. Prescott. 1985. Reorganization of DNA sequences in the life cycle of Euplotes crassus. J. Cell Biol. 101: 79-84.

Rubin, G.M., M.G. Kidwell, and P.M. Bingham. 1982. The molecular basis of P-M hybrid dysgenesis: The nature of induced mutation. Cell 29: 987-994.

Sanger, F., S. Nicklen, and A. Coulson. 1977. DNA sequencing with chain-terminating inhibitors. Proc. Natl. Acad. Sci. 74: 5463-5467.

Sheperd, J.C.W. 1981. Method to determine the reading frame of a protein from the purine/pyrimidine genome sequence and its possible evolutionary justification. Proc. Natl. Acad. Sci. 78: 1596-1600.

Southern, E.M. 1975. Detection of specific sequences among DNA fragments separated by gel electrophoresis. I. Mol. Biol. 98: 503-517.

Swanton, M.T., A.F. Greslin, and D.M. Prescott. 1980a. Arrangement of coding and non-coding sequences in the DNA molecules coding for rRNAs in Oxytricha sp. Chromosoma 77: 203-215.

Swanton, M.T., J.M. Heumann, and D.M. Prescott. 1980b. Gene-sized DNA molecules of the macronuclei in three species of hypotrichs: Size distribution and absence of nicks. Chromosoma 77: 217-227.

Wood, W.I., J.G. Gitschier, L.A. Lasky, and R.M. Lawn. 1985. Base composition-independent hybridization in tetramethylammonium chloride: A method for oligonucleotide screening of highly complex gene libraries. Proc. Natl. Acad. Sci. 82: 1585-1588.

Yao, M.-C., S. Yokoyama, C.F. Austerberry, and C.-H. Yao. 1984. DNA elimination in Tetrahymena: A developmental process involving extensive breakage and rejoining of DNA at defined sites. Cell 36: 433-440. 


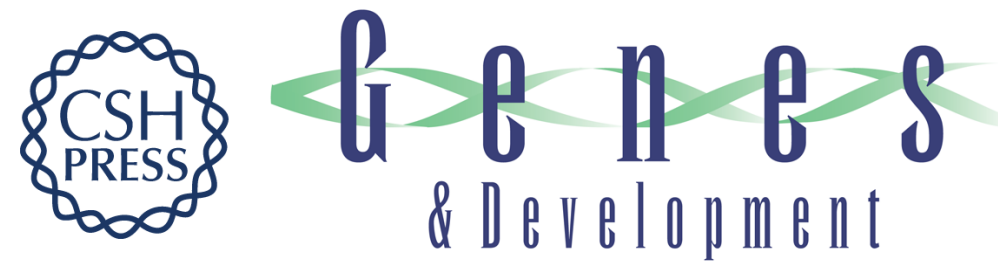

\section{Nucleic acid splicing events occur frequently during macronuclear development in the protozoan Oxytricha nova and involve the elimination of unique DNA.}

R M Ribas-Aparicio, J J Sparkowski, A E Proulx, et al.

Genes Dev. 1987, 1:

Access the most recent version at doi:10.1101/gad.1.4.323

References This article cites 54 articles, 12 of which can be accessed free at: http://genesdev.cshlp.org/content/1/4/323.full.html\#ref-list-1

License

Email Alerting Service

Receive free email alerts when new articles cite this article - sign up in the box at the top right corner of the article or click here.

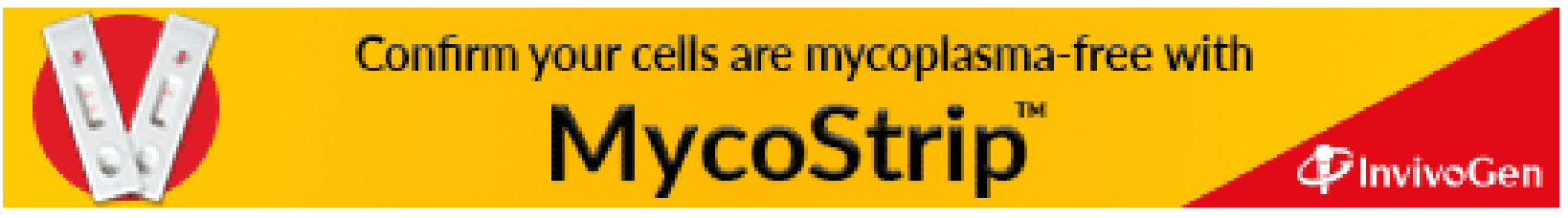

